Persoz, F. 1969: Evolution plutonique et structurale de la presqu' île d'Akuliaruseq, Groenland méridional. Bull. Gronlands geol. Unders. 72 (also Meddr Gronland 175, 3) 202 pp.

Sutton, J. \& Watterson, J. 1968: The flat-lying metamorphic complex and related igneous rocks of the Kap Farvel area. Rapp. Gronlands geol. Unders. 15, 58-60.

Watterson, J. 1965: Plutonic development of the Ilordleq area, South Greenland. Bull. Grønlands geol. Unders. 51 (also Meddr Gronland 172, 7) 147 pp.

\title{
FIELD MAPPING IN THE SCORESBY SUND REGION, EAST GREENLAND
}

\section{Niels Henriksen}

The third season, 1970, of the five year mapping programme in the Scoresby Sund area lasted slightly more than two months. As in the previous years the expedition was based on a special polar vessel which carried two Bell helicopters. The ship used was the 2675 ton "Perla Dan", which with a crew of 25 supported 3 smaller boats. The expedition members numbered 43, comprising 16 geological two- or three-man teams, and supporting personnel. The geological teams were divided into several working groups. Eight two-man parties worked in the crystalline complex in the inner fjord region around Rødefjord and on Milne Land. One party mapped the upper Palaeozoic sediments at Rødefjord. Five parties mapped the Mesozoic rocks on Milne Land and on south-eastern Jameson Land (see Birkelund, this report); three of these parties, in addition to mapping, undertook special palaeontological investigations along the west coast of Hurry Inlet and were financially supported by the Carlsberg Foundation. One party worked in the Tertiary basalt on southeastern Milne Land and north-west Gåseland, and one party undertook a Quaternary geological investigation in the central part of the inner fjord zone.

During the season logistic co-operation between prospecting groups from "Nordisk Mineselskab" and the GGU expedition benefited both groups.

Approximately $6000 \mathrm{~km}^{2}$ were mapped in the crystalline complex and about 1200 $\mathrm{km}^{2}$ in the Mesozoic sediments at a scale of 1:50 000. After three seasons' mapping the field work between $70^{\circ} 40^{\prime}$ and $72^{\circ} 00^{\prime} \mathrm{N}$ in the inner fjord zone is almost completed.

The crystalline complex

In the part of the inner Scoresby Sund region hitherto mapped by GGU it has been possible to distinguish the following main units among the crystalline rocks: 1) a pre-Caledonian basement more or less reworked by the Caledonian events; 2) two supracrustal sequences - the Charcot Land sequence and the Krummedal 
sequence - of which the former could be of a pre-Caledonian age and the latter could correspond to deposits formed in the Caledonian geosyncline; 3) Caledonian migmatites mainly formed by migmatisation of rocks belonging to the Krummedal supracrustal sequence, and 4) syn- to post-kinematic intermediate to acid intrusions mainly confined to the migmatite region (Henriksen \& Higgins, 1970).

The areas mapped in 1970 form the direct southward continuation of the areas mapped the two previous years in the inner fjord zone. Mapping this year included western and south-western Renland, northern Milne Land, Storø and the inland and nunatak region west of Rypefjord and Rødefjord north of Rolige Bræ.

The crystalline complex mapped this year can be divided into a western schist and gneiss region and an eastern migmatite region.

The western region, west of Rødefjord and Rypefjord, includes supposed basement enclaves which underlie Caledonian schists and gneisses. The presumed basement rocks generally comprise veined gneisses with amphibolite bands, with in places discordant amphibolitic dykes. This rock complex is strongly reminiscent of the Flyverfjord infracrustal complex (basement), which in the area to the north could be shown to underlie the Krummedal supracrustal sequence (Henriksen \& Higgins, 1969). In the area mapped this year the relation between the presumed basement and the cover is less distinct, as in many cases the two units are severely folded together, and in other cases they are separated by thrust planes.

A thick sequence of rusty-brown garnet-kyanite mica schist and micaceous gneisses is found above the amphibolite-banded and veined "basement", gneisses. These mica schists form the southern continuation of the rocks which form the Krummedal supracrustal sequence described from the region to the north. However, they differ from them in that they contain locally bands of amphibolitic rocks (former sills?) and some large lenses of ultramafic rocks. Massive mica schists, interbanded quartzites and mica schists, and siliceous schists are the main types of supracrustals found in the area. The more gneissic parts of these Caledonian rocks are locally somewhat migmatised.

Remnants of the Charcot Land supracrustal sequence have only been identified with certainty in the north-westernmost corner of the nunatak zone. Some greenschist facies rock complexes on the nunataks farther south might, however, also belong to this sequence and occur as a tectonic window beneath a thrust mass of Caledonian mica schists and older rocks.

In the eastern migmatite region, east of Rødefjord and Rypefjord, the infracrustals are made up of migmatised rusty-brown garnet-biotite gneisses with abundant quartzite bands. These gneisses are intruded by extensive sheets of synkinematic granites, which now occur as conformable foliated augen granites. The gneisses and augen granites are folded into major recumbent folds. A series of intermediate rocks were subsequently intruded in sheet and dyke-like bodies, and this event was followed by a second stage of migmatisation (Chadwick, in press). This later period of migmatisation resulted in places in the formation of homogeneous granitic bodies, 
which pass gradually into a sequence of late to post-kinematic granitic sheet-like intrusions capping the higher parts of Milne Land.

The structural features in the western area indicate the existence of early flatlying recumbent macroscopic folds, which later were refolded in large scale warps with north-south trending nearly vertical axial planes. Several thrust planes have been identified in this zone confirming that thrust tectonics played an important role in the deformation of the inner part of the Caledonian fold belt of the Scoresby Sund region.

In the migmatite region to the east it is also possible to distinguish an early phase of folding represented by flat-lying, tight to isoclinal, macroscopic structures, which was followed by a gentle phase of folding which produced major warps, often northsouth trending with steeply inclined axial planes.

The northern part of east Milne Land is formed by a fault block made up of supracrustals and an intrusive complex. The supracrustal sequence is composed of quartzitic and pelitic rocks with a few thick marble bands. After folding, these sediments were invaded by a suite of granodioritic, quartz-syenitic and granitic rocks presumably belonging to a Caledonian intrusive complex of post-kinematic age. The intrusions were peneplained and unconformably overlain by the Mesozoic sediments and Tertiary plateau basalts, both of which are younger than the fault separating the intrusive complex from the migmatites to the west.

\section{"Røde Ø conglomerate"}

The unfossiliferous, red conglomerate formation found along Rødefjord was mapped and the sedimentological features were studied. The "Røde $\varnothing$ conglomerate" seems to have developed as a series of alluvial fans building up to the east of an area in rapid uplift. To the west it is fault bordered, but to the east the few outcrops indicate that this boundary is an unconformity.

Four main lithologies are recognised in the formation: 1) conglomerates, 2) crossbedded, coarse sandstones, 3) medium-grained silty sandstones, and 4) mediumgrained silty sandstones with gypsum.

The "Røde $\varnothing$ conglomerate" formation was shown to be post-Caledonian and to pre-date Tertiary basic dykes. It is probably late Palaeozoic in age.

\section{Tertiary basalts}

Mapping of the Tertiary basalts this year was concentrated in southern Milne Land and in the inner part of north-western Gåseland. The sections examined had only a small vertical range compared to those investigated in previous years farther to the south. Emphasis was put on lateral correlation and it was possible to achieve a fairly detailed three-dimensional picture of the basalts within the two areas investigated. 
The investigation has shown that the characteristic flows are broad sheets measuring several hundred square kilometres representing typical flood basalts.

The study of the direction of magnetisation of the basalt flows using a hand compass was continued. In the short vertical range investigated the direction of magnetisation is almost entirely reversed except for a few flows which are anomalous.

A swarm of approximately east-west trending basaltic dykes on south-east Milne Land cuts both the Mesozoic sediments and the plateau basalts to the west.

\section{Quaternary}

Investigations of ice margin features and marine deposits were undertaken along Fønfjord, Rødefjord, Harefjord and Rypefjord.

In the outer part of Fønfjord traces of two glacial advances were identified. These two stages are separated by a marine level about $100 \mathrm{~m}$ above sea level. A younger marine level at about $90 \mathrm{~m}$ is probably synchronous with the moraine ridges and kame terraces formed during the younger glacial advance.

In the inner fjord region kame terraces and moraine ridges indicate a gradual retreat of the glaciers through the fjords. Shorelines are found at $60 \mathrm{~m}$ and at $40 \mathrm{~m}$ above sea level. Shell-bearing clay deposits are locally found up to about $60 \mathrm{~m}$ above sea level. Shells from these deposits were collected for C-14 dating. Drill core samples were collected from a few post-glacial lake deposits on Milne Land and west of Rypefjord.

\section{References}

Chadwick, B. (in press): Preliminary account of the geology of south-east Renland, Scoresby Sund, East Greenland. Rapp. Gronlands geol. Unders. 34.

Henriksen, N. \& Higgins, A. K. 1969: Preliminary results of mapping in the crystalline complex around Nordvestfjord, Scoresby Sund, East Greenland. Rapp. Gronlands geol. Unders. 21, 3-20.

Henriksen, N. \& Higgins, A. K. 1970: Preliminary results of mapping in the crystalline complex of Renland, the southern Stauning Alper and south-west Liverpool Land, Scoresby Sund, East Greenland. Rapp. Grenlands geol. Unders. 30, 5-17.

\section{FIELD MAPPING IN JURASSIC AND LOWER CRETACEOUS SEDIMENTS OF JAMESON LAND AND MILNE LAND}

\section{T. Birkelund}

In the third year of the five year project of mapping the Scoresby Sund region five field parties spent the seven-week season in the Mesozoic of Jameson Land and Milne Land. Three of the parties were sponsored by the Carlsberg Foundation and one of the participants, Dr. J. H. Callomon, by the Royal Society of London. 